\title{
Isolation of a toga-like virus from farmed Atlantic salmon Salmo salar with pancreas disease
}

\author{
R. T. Nelson, M. F. McLoughlin, H. M. Rowley, M. A. Platten, J. I. McCormick \\ Fish Diseases Unit, Veterinary Sciences Division, Department of Agriculture for Northern Ireland, Stormont, Belfast BT4 3SD,
} Northern Ireland, UK

\begin{abstract}
Pancreas disease (PD) of farmed Atlantic salmon Salmo salar has been recognised in Scotland, Ireland, Norway, the USA, France and Spain and can cause severe economic loss. This paper reports the isolation, from $\mathrm{PD}$-affected fish, of a virus with physicochemical characteristics and morphology resembling members of the Togavindae. When noculated into Atlantic salmon post-smolts it causes pathological changes in pancreas, heart and muscle tissues which are indistinguishable from those present in field outbreaks of PD. It is proposed that the virus be named salmon pancreas disease virus (SPDV).
\end{abstract}

KEY WORDS: Pancreas disease-PD Atlantic salmon Toga-like SPDV

\section{INTRODUCTION}

Pancreas disease (PD) of farmed Atlantic salmon Salmo salar was first described in Scotland in 1984 (Munro et al. 1984) although it has been recognised there since 1976. It was subsequently reported in Ireland, Norway, the USA, France and Spain (Kent \& Elston 1987, Poppe et al. 1989, Raynard et al. 1992). It causes major economic losses to the industry, with up to $50 \%$ mortalities reported by Wheatley (1994) in first year smolts in Ireland. Results of epidemiological studies and transmission experiments (McVicar 1987, 1990, Murphy et al. 1992, Raynard \& Houghton 1993) suggested an infectious aetiology for the disease. However, previous attempts to isolate an infectious agent were not successful (Munro et al. 1984, McVicar 1987, Murphy et al. 1992). This paper describes the isolation, from an outbreak of PD in Ireland, of a spherical virus $65.5( \pm 4.3) \mathrm{nm}$ in size, which morphologically resembles members of the Togaviridae. When inoculated into Atlantic salmon post-smolts it produces pathological changes in the pancreas, heart and skeletal muscle tissues, which are indistinguishable from those observed in natural outbreaks of PD on commercial salmon farms (Munro et al. 1984, Ferguson et al. 1986, Murphy et al. 1992). Hereafter this isolate is referred to as salmon pancreas disease virus (SPDV).

\section{MATERIALS AND METHODS}

Cell cultures. The following cell lines were used: chinook salmon embryo (CHSE-214), epithelioma papulosum cyprini (EPC), fathead minnow (FHM), bluegill fry (BF-2), Atlantic salmon (AS), rainbow trout gonad (RTG-2) cells and a rainbow trout fibroblast cell line produced in this laboratory (RTF). Cells were maintained in Eagle's minimum essential medium (MEM) containing Earle's salts and sodium bicarbonate (2.2 $\left.\mathrm{g} \mathrm{l}^{-1}\right)$, supplemented with $200 \mathrm{mM}$ L-glutamine, $1 \%$ non-essential amino acids, $0.01 \mathrm{M}$ Hepes, $100 \mathrm{IU}$ penicillin $\mathrm{ml}^{-1}, 100 \mu \mathrm{g} \mathrm{ml}^{-1}$ streptomycin and $10 \%$ foetal bovine serum, FBS (Gibco, Paisley)

Cells were propagated in either $150 \mathrm{~cm}^{2}$ flasks or 24 -well plates (Costar) at $20^{\circ} \mathrm{C}$. Plates were incubated in closed containers in a $3 \% \mathrm{CO}_{2} / 97 \%$ air atmosphere. For maintenance medium (MEMM) used during virus isolation attempts, antibiotics were increased as follows: penicillin, $500 \mathrm{IU} \mathrm{ml}^{-1}$; streptomycin sulphate, $500 \mu \mathrm{g} \mathrm{ml}^{-1}$; amphotericin B, $0.625 \mu \mathrm{g} \mathrm{ml}^{-1}$; and FBS was reduced to $2 \%$

Virus isolation. Samples of kidney, spleen, heart, liver, pancreas and gut were taken from 20 individual fish during the acute phase of an outbreak of $\mathrm{PD}$ in farmed Atlantic salmon on the west coast of Ireland. Samples from each fish were treated separately. 
For isolation attempts by co-cultivation, half-portion aliquots of each kidney were fragmented by placing them in a $2 \mathrm{ml}$ syringe and forcing them through a 16 gauge hypodermic needle into $10 \mathrm{ml}$ of MEMM. The tissue pieces obtained were added to monolayers of CHSE-214 cells prepared $24 \mathrm{~h}$ previously. These were incubated at $15^{\circ} \mathrm{C}$ for $28 \mathrm{~d}$ or until a cytopathic effect (CPE) was observed. Further passage in CHSE-214 cells and incubation for $28 \mathrm{~d}$ was then carried out.

The remaining kidney portions and other tissues from each fish were pooled, ground with a pestle and mortar and 10\% homogenates prepared in MEMM. They were centrifuged at $2500 \times \mathrm{g}$ for $15 \mathrm{~min}$ and $0.1 \mathrm{ml}$ of the supernatants were inoculated at final dilutions of $1: 20,1: 50$ and 1:100 in MEMM, into 24-well piates containing CHSE-214 celis. These were incubated at $15^{\circ} \mathrm{C}$ for up to $28 \mathrm{~d}$, then further passaged into CHSE-214 cells and incubated for $28 \mathrm{~d}$ at $15^{\circ} \mathrm{C}$.

SPDV growth in CHSE-214 cells. Virus growth in CHSE-214 cells was measured by inoculation of a suspension of SPDV onto CHSE-214 cells in a 24 -well plate at a multiplicity of infection (MOI) of 1 and allowing virus to absorb for $1 \mathrm{~h}$ at $15^{\circ} \mathrm{C}$. The inoculum was removed and the cells washed 3 times with MEMM, before replacing $1 \mathrm{ml}$ MEMM. Samples were removed for assay at $0,2,4,6,8,10,12,14,21$ and $28 \mathrm{~d}$ postinoculation (dpi) as follows. Half of the culture medium was removed from each of 4 wells, pooled and centrifuged at $800 \times g$ for 5 min to remove the cells. The supernatant contained extracellular virus. The remaining $0.5 \mathrm{ml}$ of culture medium, along with the adherent cells removed by scraping, was pooled, and frozen and thawed once. This represented total virus present. Both samples were assayed separately for virus infectivity by titration in CHSE-214 cells incubated at $15^{\circ} \mathrm{C}$ for $14 \mathrm{~d}$. The $50 \%$ end points in this and all subsequent tests were estimated by the method of Reed \& Muench (1938).

Growth of SPDV in various cell cultures. Ten-fold dilutions of a virus pool containing $10^{7} \mathrm{TCID}_{50} \mathrm{ml}^{-1}$ were inoculated into AS, BF-2, FHM, EPC, RTG-2 and RTF cells incubated at $15^{\circ} \mathrm{C}$ for $14 \mathrm{~d}$. Any CPE was noted and cultures were tested for virus growth by titration of culture fluids in CHSE-214 cells. All cultures were also given 1 further passage for $14 \mathrm{~d}$ in the same cells at $15^{\circ} \mathrm{C}$, and checked again for virus growth in CHSE-214 cells before discarding.

Chloroform sensitivity. Sensitivity to chloroform was determined by adding $0.05 \mathrm{mi}$ chloroform to $1 \mathrm{ml}$ of SPDV. The mixture was shaken for $10 \mathrm{~min}$ at room temperature, then centrifuged at $400 \times g$ for 5 min to remove the chloroform. Presence of infectious virus was detected by titration in CHSE-214 cells. One control consisted of $0.05 \mathrm{ml}$ of MEMM added to $1 \mathrm{ml}$ of virus. Infectious pancreatic necrosis virus (IPNV) and infectious haematopoietic necrosis virus (IHNV) were also included as non-sensitive and sensitive virus controls respectively.

Stability at pH 3.0. Stability at pH 3.0 was determined by adding $0.1 \mathrm{ml} \mathrm{SPDV}$ to $0.9 \mathrm{ml}$ MEM adjusted to $\mathrm{pH} 3.0$, holding for $4 \mathrm{~h}$ at $4^{\circ} \mathrm{C}$, and then determining presence of infectious virus by titration in CHSE-214 cells. SPDV was added to MEM at pH 7.2 as a control, IPNV was included as a $\mathrm{pH} 3.0$ stable virus control and IHNV as a pH 3.0 sensitive control.

Temperature stability. Aliquots of viral suspensions were heated for $30 \mathrm{~min}$ at $15,25,37,45,50,55$ or $60^{\circ} \mathrm{C}$, and then cooled immediately by immersion in ice water. The concentration of infectious virus remaining was assayed by titration in CHSE-214 cells.

Nucleic acid inhibition test. The nucleic acid type of the virus was presumptively determined by growing it in the presence of the DNA inhibitor 5-bromo-2'deoxyuridine (BUDR) with and without thymidine (THY). Groups of 4 wells in each of three 24 -well plates containing CHSE-214 cells were inoculated with $0.1 \mathrm{ml}$ of 10 -fold dilutions of virus, which were allowed to absorb for $1 \mathrm{~h}$ at $15^{\circ} \mathrm{C}$. To each plate, either $1 \mathrm{ml}$ of MEMM alone, MEMM with $1 \mathrm{mM}$ BUDR or MEMM with $1 \mathrm{mM}$ BUDR and $1 \mathrm{mM}$ THY was added. The plates were incubated at $15^{\circ} \mathrm{C}$ for $14 \mathrm{~d}$ and examined for CPE. An RNA virus (IPN) grown in CHSE-214 cells, and a DNA virus (lymphocystis) grown in BF-2 cells, were included as controls.

Negative contrast electron microscopic (EM) examination. Virus suspensions for EM examinations consisted of either SPDV-infected cell culture medium used without prior fixation or after the addition of glutaraldehyde ( $2 \%$ final conc.) for $1 \mathrm{~h}$ at $4^{\circ} \mathrm{C}$ and subsequent ultracentrifugation at $100000 \times g$ for $4 \mathrm{~h}$, then resuspending the pellet in a few drops of distilled water. A carbon coated copper grid was placed on top of a drop of virus suspension and allowed to stand for $10 \mathrm{~min}$. Excess fluid was drained off and the grid was stained with $2 \%$ phosphotungstic acid (PTA), pH 7.2, for 1 min. Virus was examined using a Hitachi $\mathrm{H} 7000$ transmission EM at $\times 50000$ magnification.

Caesium chloride density gradient centrifugation. SPDV was inoculated into CHSE-214 cells at a MOI of 1 . At $8 \mathrm{dpi}$, cells and medium $(400 \mathrm{ml})$ were harvested after freezing and thawing and then centrifuged at $10000 \times g$ for $30 \mathrm{~min}$ in a Beckman Type 35 angle rotor to remove cell debris. The supernatant was subjected to ultracentrifugation at $100000 \times g$ for $4 \mathrm{~h}$. The resultant pellet was resuspended in a total of $2 \mathrm{ml}$ of phosphate-buffered saline (PBS), $\mathrm{pH} 7.2$, layered over a discontinuous caesium chloride $(\mathrm{CsCl})$ gradient comprised of $5 \mathrm{ml}$ of $1.30 \mathrm{~g} \mathrm{ml}^{-1} \mathrm{CsCl}$ and $4.5 \mathrm{ml}$ of $1.22 \mathrm{~g} \mathrm{ml}^{-1} \mathrm{CsCl}$, and centrifuged at $100000 \times \mathrm{g}$ for $19 \mathrm{~h}$ at $4^{\circ} \mathrm{C}$. Twenty fractions were collected and tested 
for infectivity in CHSE-214 cells. The density of the fractions containing infective virus was determined using a refractometer.

Haemagglutination. Tests for haemagglutination were carried out with chicken, guinea pig, rainbow trout, and Atlantic salmon erythrocytes in U-bottomed 96 -well plates, by adding $0.1 \mathrm{ml}$ of a $0.8 \%$ suspension of red blood cells in PBS, pH 7.2 to $0.1 \mathrm{ml}$ of virus $\left(10^{7} \mathrm{TCID}_{50} \mathrm{ml}^{-1}\right)$ and incubating at 4,15 , and $37^{\circ} \mathrm{C}$ Tests were examined after 1,3 and $18 \mathrm{~h}$.

Serological tests. SPDV was tested for neutralisation by hyperimmune rabbit sera to the following fish viruses: VHSV, IHNV, IPNV strains Sp, Ab, VR-299. SPDV was also tested against antisera to 2 members of the togavirus family, equine arteritis virus (EAV) and rubella virus, as well as to 1 member of the flavivirus family, bovine viral diarrhoea virus (BVDV). Antisera to alphaviruses were not available. An equal volume of SPDV (200 TCID 50 per $0.1 \mathrm{ml}$ ) was added to $0.1 \mathrm{ml}$ of 2 -fold dilutions of antisera and incubated at $15^{\circ} \mathrm{C}$ for $1 \mathrm{~h}$. The mixtures were then inoculated into CHSE-214 cells in 24-well plates, $0.1 \mathrm{ml}$ per well, allowed to absorb for $1 \mathrm{~h}$ at $15^{\circ} \mathrm{C}, 1 \mathrm{ml}$ MEMM added and incubated at $15^{\circ} \mathrm{C}$ for $14 \mathrm{~d}$. The cultures were examined microscopically on alternate days for evidence of CPE.

Experimental transmission design. Fish: Atlantic salmon post-smolts of mean weight $87 \mathrm{~g}$ were supplied, maintained and sampled by Marine Harvest Ltd, Lochailort, Scotland. They were kept in $2 \times 1.5 \mathrm{~m}$ tanks with sea water supplied as a flow-through system at 12 to $15^{\circ} \mathrm{C}$. They were maintained for $2 \mathrm{wk}$ to acclimatize prior to inoculation, and samples of tissues from 10 fish were cultured for IPNV and examined for histo. logical evidence of PD.

Inoculum 1: A virus pool was prepared by inoculating SPDV into CHSE-214 cells at a MOI of 1 and harvesting after $8 \mathrm{~d}$ incubation at $15^{\circ} \mathrm{C}$. The cells were disrupted by freezing and thawing once and the cell debris was removed by centrifugation at $10000 \times g$ for $30 \mathrm{~min}$. The resultant virus pool, with a titre of $10^{7} \mathrm{TCID}_{50} \mathrm{ml}^{-1}$, was filtered through a $0.22 \mu \mathrm{m}$ porosity Millipore filter and $0.1 \mathrm{ml}$ inoculated intraperitoneally into each of 100 fish. Fifty fin-clipped, uninoculated fish were added to each of the tanks as in-contact fish.

Inoculum 2: Controls consisted of 100 fish inoculated with a lysate from uninfected CHSE-214 cells prepared in exactly the same manner as the virus infected cells, and 50 additional in-contact control fish were added.

Sampling: On $7,10,15,21,28,35$ and 42 dpi, samples of heart, spleen, liver, caeca/pancreas and muscle were taken from 10 test and 10 control fish for histological examination. Heart, spleen, kidney and caeca/pancreas samples were also taken from the same fish for virus isolation. On 14, 21, 28, 35 and
$42 \mathrm{dpi}, 5$ in-contact fish were removed and tissues sampled for histological examination. In-contact fish were sampled for virus isolation on Days 14 and 21 only.

Histology: Samples for histological examination were fixed in $10 \%$ formaldehyde in buffered saline, $\mathrm{pH} 7.0$, embedded in paraffin wax and $5 \mu \mathrm{m}$ sections cut on a Reichert Ultracut $S$ microtome. They were stained with haematoxylin and eosin.

Virus isolation: Tissues were prepared as 10\% homogenates in MEMM using mortars and pestles, centrifuged at $2500 \times \mathrm{g}$ for $15 \mathrm{~min}$, then inoculated at final dilutions of 1:20 and 1:100 into each of 2 wells in a 24 -well plate containing CHSE-214 cells and incubated at $15^{\circ} \mathrm{C}$ for $28 \mathrm{~d}$. Samples showing no CPE were given 1 further passage into CHSE-214 cells before being considered negative.

\section{RESULTS}

\section{Virus isolation, morphology and growth characteristics}

Virus was isolated from 2 of 20 kidney tissues submitted for examination. These had been co-cultivated with CHSE-214 cells for $28 \mathrm{~d}$ and then given further passages in CHSE-214 cells. No CPE was seen in the original co-cultivation cultures. On passage, however, small discrete groups of cells which were pyknotic, vacuolated and irregular in appearance could be observed after $10 \mathrm{~d}$ incubation. After further passages in CHSE-214 cells the CPE had become widespread (Fig. 1) and appeared as early as $4 \mathrm{dpi}$. Virus titres between $10^{7.0}$ and $10^{8.0} \mathrm{TCID}_{50} \mathrm{ml}^{-1}$ were routinely attained. Most of the affected cells remained attached to the monolayers. No syncytia or inclusion bodies were observed in any of the cultures.

Virus was not isolated from any of the tissue homogenates incubated without co-cultivation. Virus yields in CHSE-214 cells are shown in Fig. 2. Highest titres were reached between 6 to $8 \mathrm{dpi}$ and these remained high for up to $14 \mathrm{~d}$.

No CPE was observed in AS, BF-2, FHM, EPC, or RTG-2 cells and there was no evidence of growth of SPDV in these cells. However, in the RTF cell line SPDV titres reached $10^{6} \mathrm{TCID}_{50} \mathrm{ml}^{-1}$ on both first and second passage in these cells, although no CPE was observed.

EM examination of the glutaraldehyde-fixed material revealed the presence of spherical particles measuring 65.5 ( \pm 4.3 ) $\mathrm{nm}$ (Fig. 3). These possessed an inner core of indefinite structure and were surrounded by an outer fringe. Many partially disrupted particles were also present. In the unfixed preparations only a few complete particles were seen and our experience indicates that the free virion is fragile and easily disrupted during preparation for EM examination. 


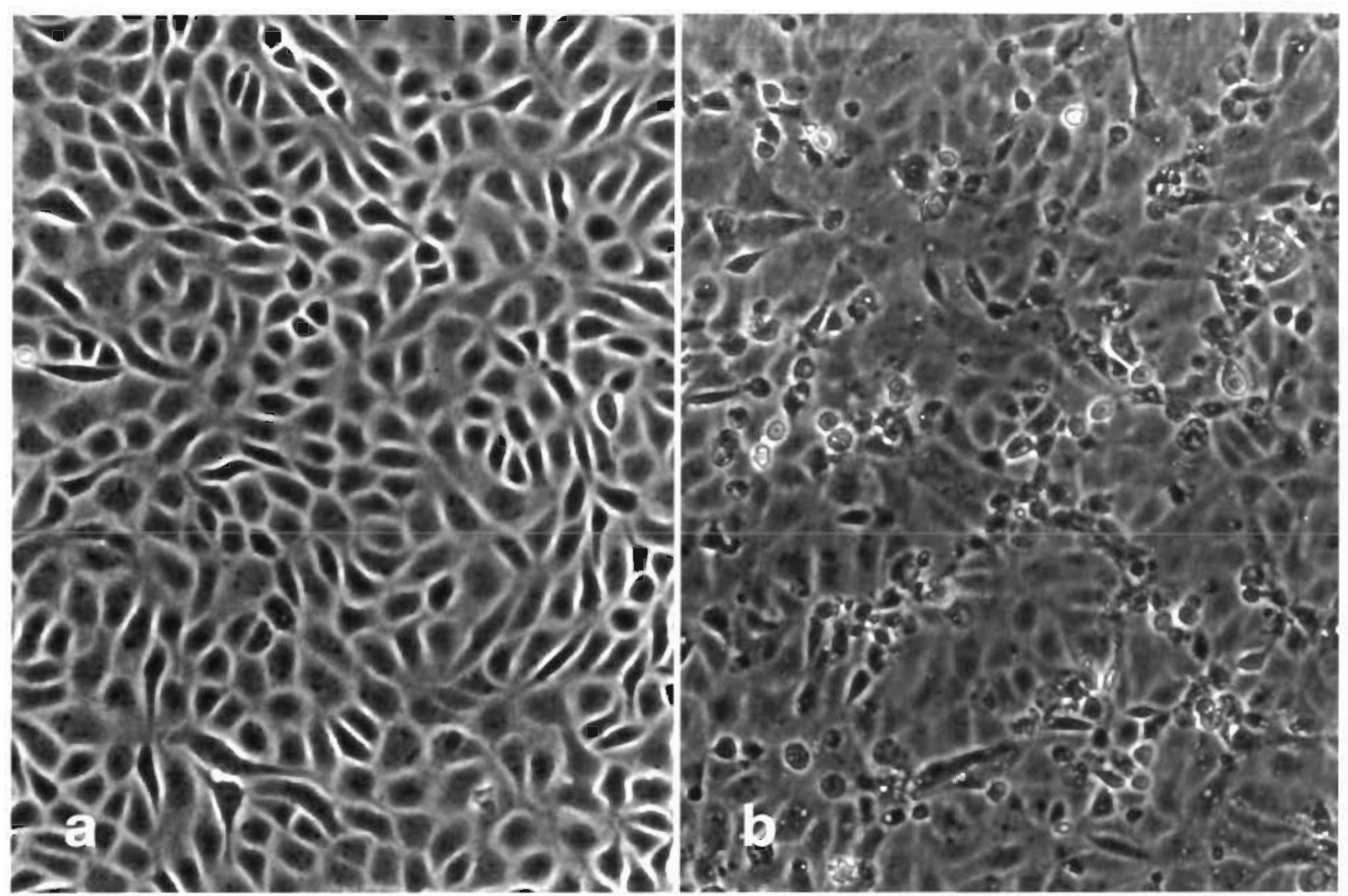

Fig. 1. Cytopathology of SPDV, isolated from Salmo salar in CHSE-214 cell cultures. (a) Uninfected cells. (b) Cells 8 d postinoculation with SPDV

\section{Physiochemical and serological characterisation}

Growth of SPDV and IPNV was not affected by the presence of BUDR in the medium (Table 1), whereas the DNA control virus (lymphocystis) was inhibited.

Infectivity of SPDV was not inactivated by incubation at 4,15 or $25^{\circ} \mathrm{C}$ but was reduced at 37 and $45^{\circ} \mathrm{C}$ while no infectious virus was detected after $30 \mathrm{~min}$ at $50^{\circ} \mathrm{C}$. Infectivities of SPDV and IHNV were reduced following exposure to chloroform, indicating the pres-

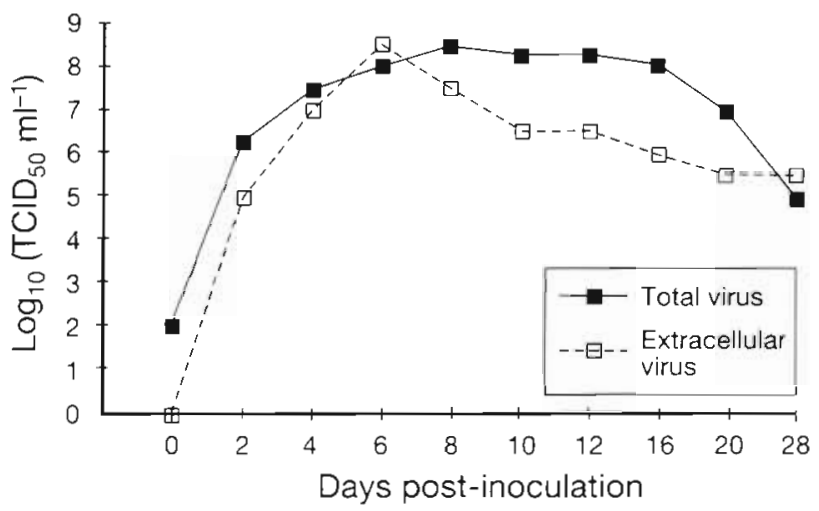

Fig. 2. Growth of SPDV, isolated from Salmo salar, in CHSE214 cells ence of a lipid-containing envelope (Table 1). In contrast IPNV infectivity was not affected when treated in the same way.

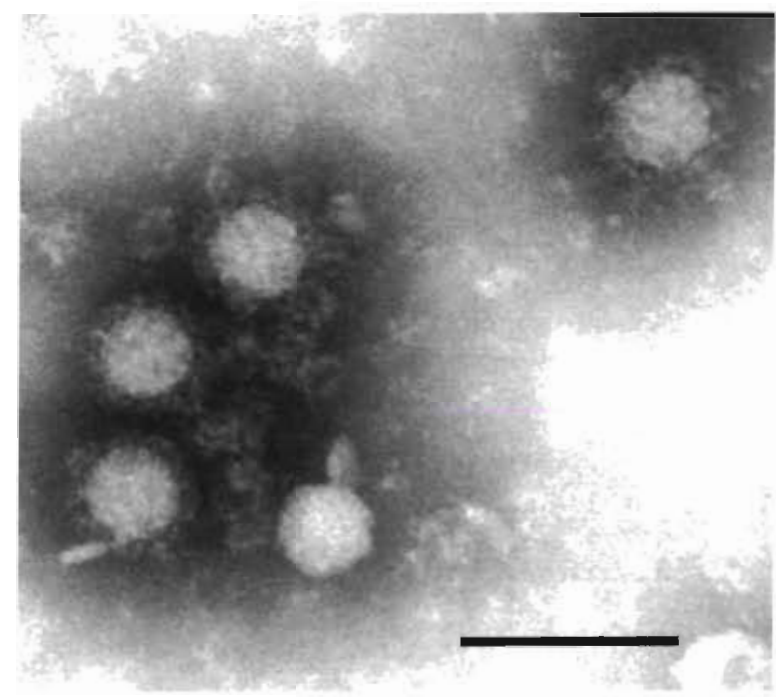

Fig. 3. Transmission electron micrograph of glutaraldehydefixed, SPDV-infected CHSE-214 cell culture fluid. Virus particles can be seen, most with surface projections but little internal structural detail. Scale bar $=100 \mathrm{~nm}$ 
The infectivity of SPDV and IHNV was destroyed when they were exposed to $\mathrm{pH}$ 3.0, while IPNV was not affected (Table 1). Infectivity was detected in fractions from $\mathrm{CsCl}$ gradients with densities from 1.08 to $1.26 \mathrm{~g} \mathrm{ml}^{-1}$, with the maximum infectivity being located at a density of $1.20 \mathrm{~g} \mathrm{~m}^{-1}$ This fraction also contained the greatest number of complete virus particles as assessed by EM examination. No haemagglutination was observed at any of the temperatures, or with any of the erythrocytes tested. In neutralisation tests SPDV was not neutralised by antisera to IHN, VHS, IPN, EA, BVD or rubella viruses.

\section{Experimental transmission results \\ Clinical and pathological lesions}

At 7 dpi, the fish inoculated with SPDV became anorexic and there was an increase in faecal casts in the tank. Focal to severe diffuse pancreatic acinar cell necrosis with concurrent multifocal cardiomyocytic necrosis was consistently observed from 7 dpi. Skeletal muscle fibre degeneration was detected at $15 \mathrm{dpi}$, affecting both red and white skeletal muscle fibres. These muscle lesions increased in frequency and severity at 35 and 42 dpi. Typical lesions observed at 21 dpi are illustrated in Figs. 4 to 7.

All the cohabitant fish developed similar lesions approximately $2 \mathrm{wk}$ after the inoculated fish. A full description of the induced lesions will be published elsewhere.

No clinical signs or lesions were detected in any of the control fish.

\section{Virus isolation}

Virus was isolated from fish inoculated with SPDV and in-contact fish from the same tank but not from any of the control fish (Table 2). No IPN virus was detected at any stage in the transmission study.

\section{DISCUSSION}

Although it has been suggested for some time that PD of farmed Atlantic salmon is caused by an infectious agent, we have found, in common with other workers, that inoculation of tissue homogenates into cell cultures did not lead to recovery of an agent. These previous failures to isolate an agent from tissue homogenates by standard methods may have been due to the presence of inhibitory substances, as reported for IPNV by Dixon (1987) and suggested for PD by Raynard \& Houghton (1993). In contrast we found that when PD-infected kidney tissues were cocultivated with monolayers of CHSE-214 cells, small foci of altered cells were observed. After further passages in CHSE-214 cells these cytopathic effects increased, until approximately $75 \%$ of the monolayer

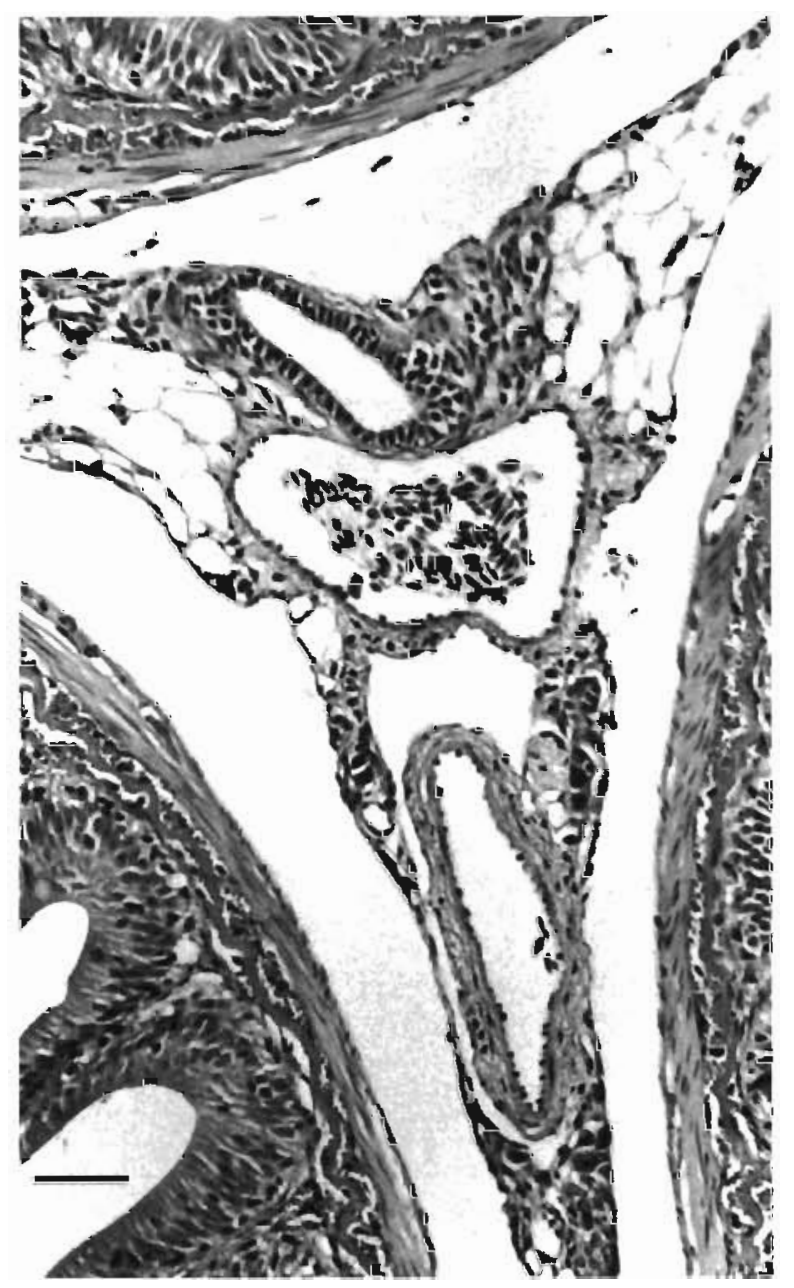

Fig. 4. SPDV infected Salmo salar. Significant pancreatic acinar cell loss typical of pancreatic lesions induced by SPDV in an experimentally infected fish, at $21 \mathrm{dpi}$. Scale bar $=50 \mu \mathrm{m}$ 


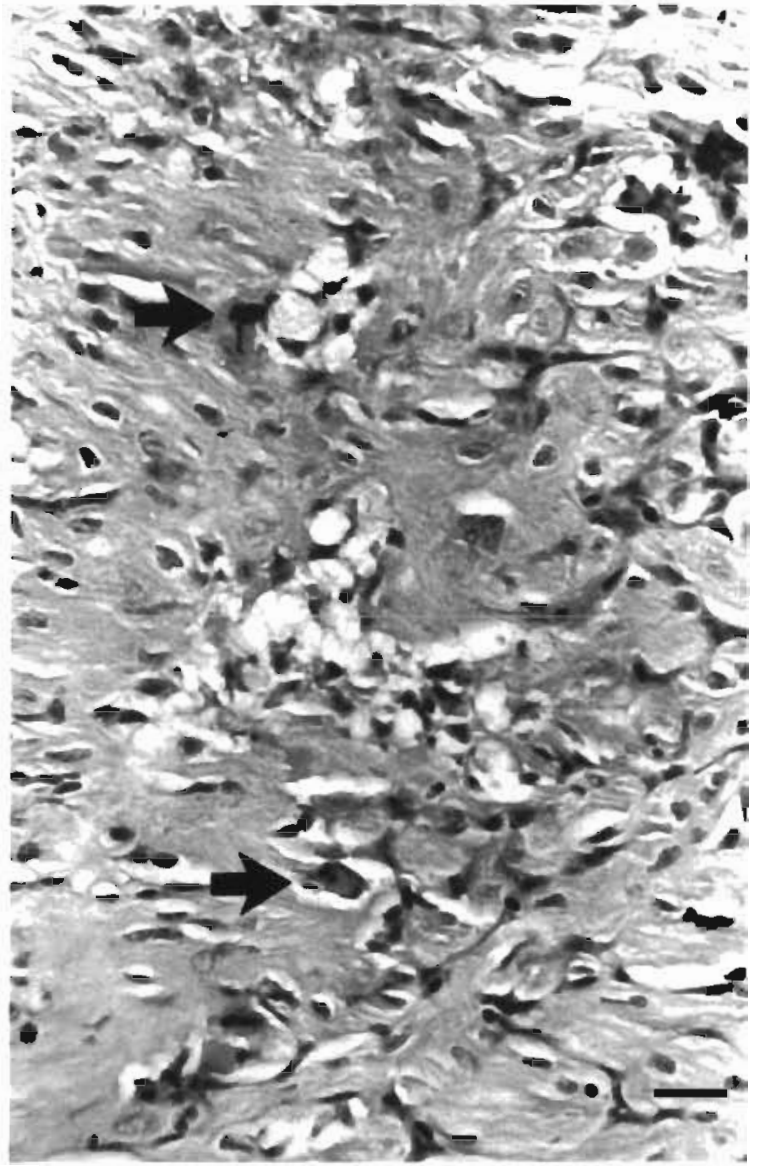

Fig. 5. SPDV infected Salmo salar. Multifocal cardiomyocytic necrosis which occurred concurrently with the pancreatic (arrows) lesions seen at $21 \mathrm{dpj}$, in an experimentally infected fish. Scale bar $=20 \mu \mathrm{m}$

was affected, although most of the cells still remained attached to the monolayer. It was found that the CHSE214 cell adapted virus, when used to reinfect fish, could thus readily be isolated from infected tissue homogenates. EM examination of glutaraldehydefixed culture fluids from infected cells revealed the presence of virus-like particles approximately $65 \mathrm{~nm}$ in diameter, showing surface projections. Many partially

Table 2. Virus isolations from Atlantic salmon Salmo salar used in transmission experiments. Values presented as no. of positive fish/no. examined. nd: not done

\begin{tabular}{|lccccc|}
\hline Fish group & \multicolumn{5}{c|}{ Days post-inoculation } \\
& 7 & 10 & 15 & 21 & 28 \\
\hline Controls $^{\text {d }}$ & $0 / 10$ & $0 / 10$ & $0 / 10$ & $0 / 10$ & $0 / 10$ \\
Virus-inoculated & $7 / 10$ & $8 / 10$ & $10 / 10$ & $3 / 10$ & nd \\
In-tank contacts & nd & nd & $5 / 5$ & $5 / 5$ & nd \\
a Inoculated with CHSE-214 cell lysate & & \\
\hline
\end{tabular}

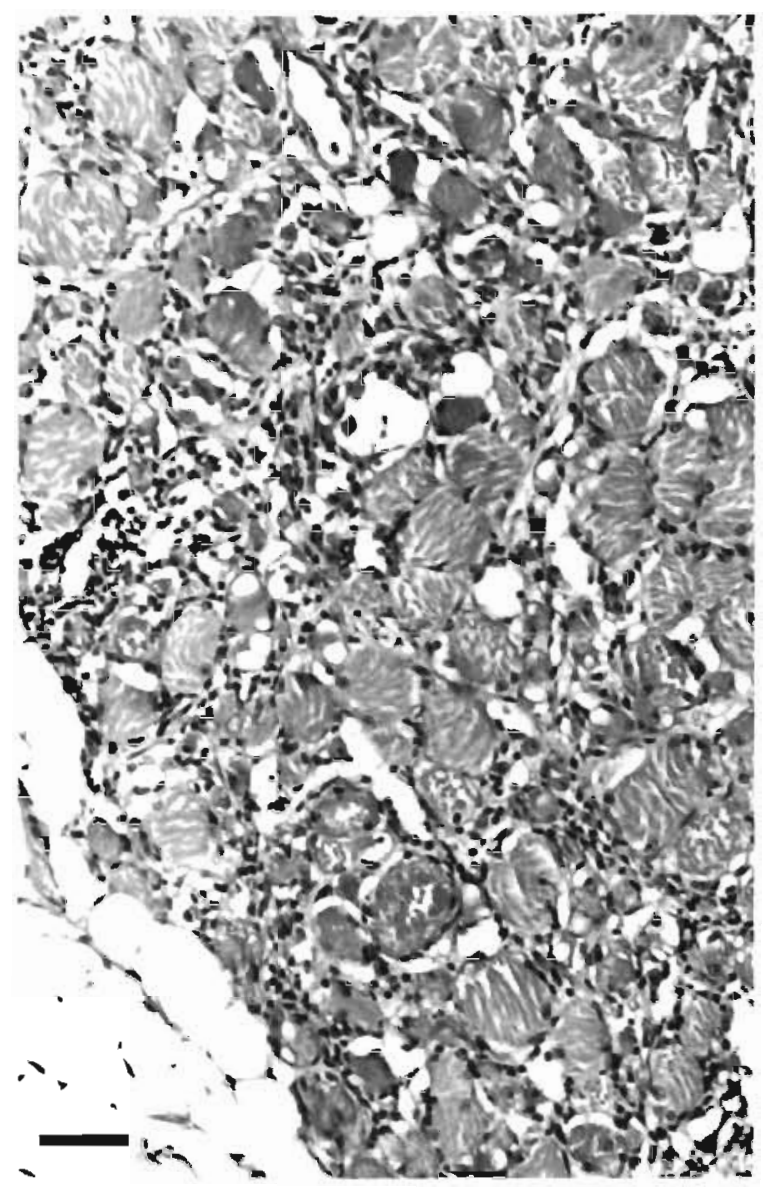

Fig. 6. SPDV infected Salmo salar. Degeneration of aerobic (red) skeletal muscle showing increased endomysial connective tissue, proliferation of sarcolemmal cells and hyaline degeneration of muscle fibres (21 dpi). Scale bar $=40 \mu \mathrm{m}$

disrupted particles could also be seen. The fact that virus preparations not fixed in glutaraldehyde before EM examination contained mostly disrupted particles indicated that prefixation was required to preserve the intact virion.

The virus was sensitive to $\mathrm{pH} 3.0$ and to chloroform, did not haemagglutinate a variety of erythrocyte species tested, was not neutralised by antisera used, and from its resistance to inhibition by BUDR appears to be an RNA virus. In $\mathrm{CsCl}$ density gradients, infectivity of the virus was detected across a broad density range with peak infectivity and greatest number of intact virus particles present at $1.20 \mathrm{~g} \mathrm{ml}^{-1}$

On the basis of virion morphology, size, nucleic acid composition and other physical characteristics the virus most closely resembles members of the Togaviridae (Strauss 1991). This family is presently comprised of 3 genera, Alphavirus (27 species), Rubivirus ( 1 species), and Arterivirus (1 species). The togaviruses are essentially isometric, enveloped particles with surface 


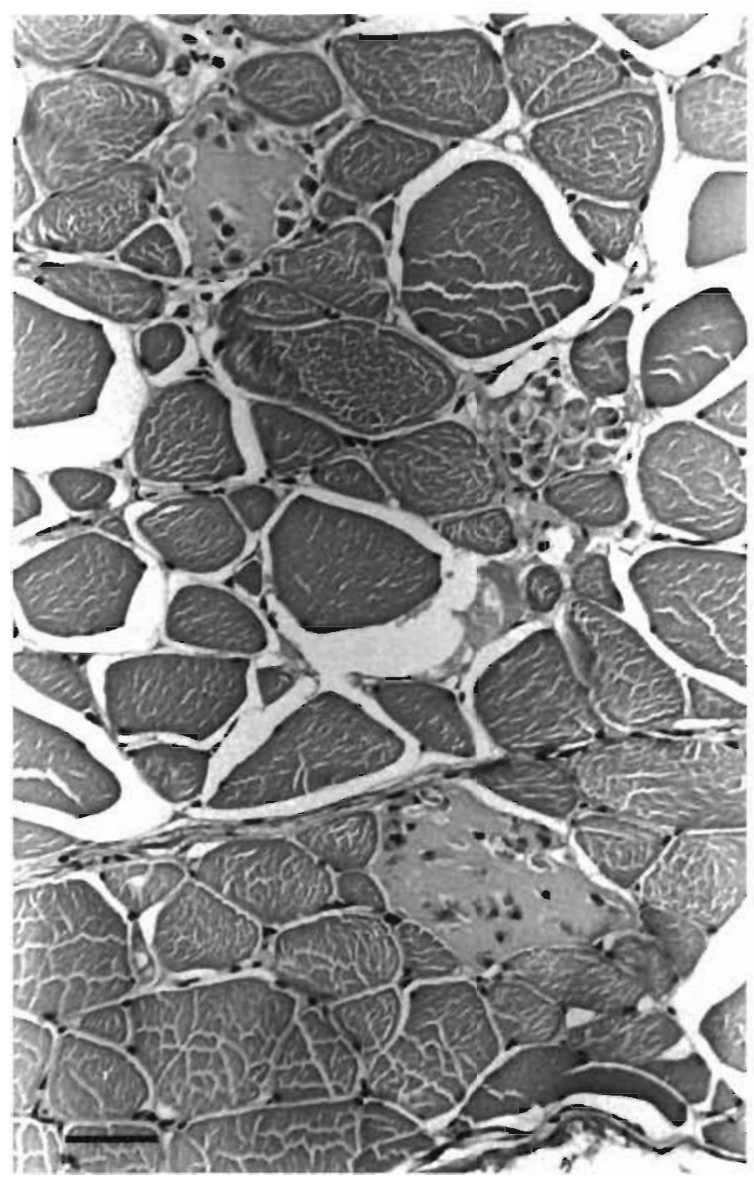

Fig. 7. SPDV infected Salmo salar. Hyaline degeneration of anaerobic (white) skeletal muscle fibres showing centralisation of muscle fibre nuclei and phagocytosis of fibre contents. Scale bar $=40 \mu \mathrm{m}$

projections, often with little internal structural detail on EM examination.

This is the first description of the isolation of a togalike virus from PD-affected farmed Atlantic salmon. No other fish viruses have been convincingly shown to be members of the togavirus family at present, although it has been suggested that erythrocytic inclusion body syndrome virus (EIBSV) of salmon is probably a togavirus (Okamoto et al. 1992). This has not been isolated to date.

Our transmission study confirmed that SPDV could cause clinical signs and pathological lesions among experimental groups of salmon smolts in seawater and these signs and lesions were indistinguishable from published descriptions of field outbreaks of PD (Munro et al. 1984, Ferguson et al. 1986, McVicar 1987, 1990, Murphy et al. 1992). The fish became anorexic, and some had faecal casts and petechial haemorrhages in the pancreatic fat. While controversy exists as to the severity and tissue distribution of histopathological lesions associated with 'classical' PD (Wheatley 1994), our findings are in close agreement with the description of Ferguson et al. (1986) of an outbreak of PD in Scotland and Murphy et al. (1992), who described the sequential pathology of $2 \mathrm{PD}$ outbreaks in Ireland. The lesions observed in our transmission studies represent the full range of acute and chronic pancreatic, cardiac and skeletal muscle lesions as observed by us in field outbreaks of PD and described by other workers. From this study we conclude that SPDV is the causative agent of $P D$ in farmed Atlantic salmon. There is evidence that fish acquire a strong immunity to PD after field and experimental exposure (Raynard \& Houghton 1993, Houghton 1994). It may therefore be possible to produce an effective SPDV vaccine. The isolation of this virus should enable the development of antigen and nucleic acid detection systems which would aid in the rapid diagnosis of PD and assist in more thorough investigations of the pathogenesis and epidemiology of this important disease of Atlantic salmon. Aspects of this work are subject to patent applications.

Acknowledgements. We thank A. Grant and D. Cox from Marine Harvest Ltd, P. Gallagher from Ocean Farm and D. Todd from Veterinary Sciences Division for their valued cooperation.

\section{LITERATURE CITED}

Dixon PF (1987) Inhibition of infectious pancreatic necrosis virus infectivity by extracts of rainbow trout, Salmo gairdneri Richardson, tissue. J Fish Dis 10:371-378

Ferguson HW, Roberts RJ, Richards RH, Collins RO, Rice DA (1986) Severe degenerative cardiomyopathy associated with pancreas disease in Atlantic salmon (Salmo salar). J Fish Dis 20:95-98

Houghton G (1994) Acquired protection in Atlantic salmon Salmo salar parr and post-smolts against pancreas disease. Dis aquat Org 18:109-118

Kent ML, Elston RA (1987) Pancreas disease in pen-reared Atlantic salmon in North America. Bull Eur Ass Fish Pathol $7: 29-31$

McVicar AH (1987) Pancreas disease of farmed Atlantic salmon, Salmo salar, in Scotland: epidemiology and early pathology. Aquaculture 67:71-78

McVicar AH (1990) Infection as a primary cause of pancreas disease in farmed Atlantic salmon. Bull Eur Ass Fish Pathol 10:84-87

Munro ALS, Ellis AE, McVicar AH, McLay HA (1984) An exocrine pancreas disease of farmed Atlantic salmon in Scotland. Helgoländer Meeresunters 37:571-586

Murphy TM, Rodger HD, Drinan EM, Gannon F, Kruse P, Körting W (1992) The sequential pathology of pancreas disease in Atlantic salmon farms in Ireland. J Fish Dis 15:401-408

Okamoto N, Takahashi K, Maita M, Rohovec JS, Ikeda Y (1992) Erythrocyte inclusion body syndrome: susceptibility of selected sizes of salmonid fish. Fish Pathol 27 : 153-156 
Poppe T, Rimstad E, Hyllseth B (1989) Pancreas disease in Atlantic salmon (Salmo salar) post smolts infected with infectious pancreatic necrosis virus (IPNV). Bull Eur Ass Fish Pathol 9:83-85

Raynard RS, Houghton G (1993) Development towards an experimental protocol for the transmission of pancreas disease of Atiantic salmon Salmo salar. Dis aquat Org 15 $123-128$

Raynard R, Houghton G, Munro ALS (1992) Pancreas disease of Atlantic salmon: proceedings of a European Commission workshop. Scottish Office Aquaculture Report No 1 The

Responsible Subject Editor: F. M. Hetrick, College Park, Maryland, USA
Scottish Office Agriculture and Fisheries, Aberdeen, p 2-4 Reed LJ, Muench $H$ (1938) A simple method of estimating fifty percent end points. Am J Hygiene 27:493-497

Strauss JH (1991) Togaviridae. In: Francki RIB, Fauquet CM, Knudson DL, Brown F (eds) Archives of virology, Supplement 2, classification and nomenclature of viruses. Fifth Report of the International Committee on Taxonomy of Viruses. Springer-Verlag, Vienna, p 216-222

Wheatley SB (1994) Epidemiological investigations of Atlantic salmon production using a computerised database system. PhD thesis, Queens University, Belfast, p 62

Manuscript first received: October 20, 1994

Revised version accepted: January 1, 1995 